UDC 347.156

DOI https://doi.org/10.32849/2663-5313/2021.8.03

Aneesh V. Pillai,

PhD, Assistant Professor, School of Legal Studies of Cochin University of Science and Technology, Kalamassery, Kochi Kerala, India, postal code 682022, advavpillai@gmail.com,dr.avpillai@cusat.ac.in ORCID: orcid.org/0000-0002-1889-8221

Anatoliy Kostruba,

Doctor of Law, Professor at the Department of Civil Law, Vasyl Stefanyk Precarpathian National University, 57, Shevchenko street, Ivano-Frankivsk, Ukraine, postal code 76000, anatolii.kostruba@pnu.edu.ua ORCID: orcid.org/0000-0001-9542-0929

Scopus Author ID: 57197823711

Pillai Aneesh V., Kostruba, Anatoliy (2021). Women's reproductive rights and their scope under international legal frameworks. Entrepreneurship, Economy and Law, 8, 18-28.

\title{
WOMEN'S REPRODUCTIVE RIGHTS AND THEIR SCOPE UNDER INTERNATIONAL LEGAL FRAMEWORKS
}

Abstract. The article is devoted to the problem of nature and role of individual's reproductive rights in the system of private moral right. The purpose of the contribution is to study the legal regulation of reproductive rights of women in India and Ukraine and analyse the features of some reproductive rights, which are carried out with the help of assisted reproductive technologies with an emphasis on issues related to surrogacy, case law on this issue. Research methods. The paper is executed by applying the general research and special methods of scientific cognition.

Results. Reproductive rights generally mean the right of an individual to control the process of reproduction. It includes the right to decide whether to have or not to have a child, the number and spacing of children; access to reproductive services etc. Considering the importance of human reproduction, the reproductive rights are declared as fundamental human rights. However, at the international and national levels, there is no a single document which explains the scope of reproductive rights. In the absence of such a document, the reproductive rights raise several questions. For example, the scope of this right to an aged or disabled person or a transgender or a prisoner etc. is a million-dollar question which does not have a specific answer. Since the women's empowerment includes women's reproductive empowerment, a clear and reasonable answer is required for achieving the aim of reproductive empowerment. A detailed examination of legal frameworks both at international and national levels is necessary to answer these questions.

Conclusions. Scientific positions on reproductive rights are substantiated. It is emphasized that reproductive rights are the rights of the latest, fourth generation of human rights, and are derived from personal rights. It is noted that human reproductive rights are both natural and those that are carried out with the use of assistive technologies. The article deals with the basic types of reproductive rights, including the right to artificial insemination, surrogacy, sterilization, prevention and treatment of infertility, abortion, organ donation and reproductive cells, the use of contraception, the right to reproductive choice, the right to reproductive health, right to information about reproductive rights, the right to privacy to implement reproductive rights and others. The necessity of adopting the special legislative act in the sphere of reproductive rights and reproductive health is grounded.

Key words: reproductive rights, personal rights, personality, medical law, human rights, right to privacy, abortion, sterilization, assisted reproductive technologies, surrogacy, artificial insemination, medical tourism.

\section{Introduction}

The need and importance of a child is recognized by almost all religions all over the world. Begetting a child is one of the most joyful moments in the life of a person. In fact, begetting a child is considered a sacred duty of an individual to his/her family and society and this duty is usually fulfilled through the institution of marriage. The act of reproduction is usually a natural process of sexual union between cou- 
ples which requires no external interference from a third party. Hence, reproductive rights are declared as fundamental human rights both at international and regional frameworks of human rights. Although it is an accepted fact that every individual has the right to claim reproductive rights, the exercise of this right in certain situations may raise serious legal and human rights concerns.

The past few decades have seen increasing recognition of the process of women empowerment. The international community has taken several measures for ensuring empowerment of women. It can be seen that most of these measures concentrate on the economic and political empowerment of women. The problems of consolidating and protecting the reproductive rights of citizens have recently become especially important for Ukrainian, as well as for Indian, society given the demographic crisis situation in our country. The empowerment of women is not only limited to mainstreaming the women or equipping them to be part of economic and political process but also includes equipping women to control each and every aspect affecting their life. One of such important aspects of women's life which requires immediate attention is their reproductive rights or, in other words, the process of women's reproductive empowerment. Women's reproductive empowerment in its true spirit is possible only if there is a sufficient understanding about and access to the reproductive rights. Therefore, it is necessary to understand the scope and ambit of reproductive rights of women. This chapter seeks to examine both international and national legal frameworks on reproductive rights to identify the scope and limitations of this right.

2. Reproductive rights: concept and meaning

Reproductive rights are considered to be the so-called newest personal non-property rights of the fourth generation, which are closely linked to the inalienable human right to life, respect for one's dignity, personal integrity, etc.

It is a natural instinct of every living creature to have an offspring and it's in high pedestal when it comes to human beings. It is not only because of natural desires but also because of psychological and social needs to have children (Erikson, 2000). The reproductive rights are those rights which enable an individual to procreate his or her offspring. There is no legal definition of "reproductive rights" in India, as well as in Ukraine. Legal regulation of this issue is carried out on the basis of the norms of the Civil Code, Family Code. Although there is no single accepted definition for the term of reproductive rights, the most cited defini- tion is provided in the International Conference on Population and Development, 1994. It says that reproductive rights are recognized as a part of human rights by several national jurisdictions and also at international level. This right allows every couple to control their pregnancy, decide about when and how many etc. The right to access to reproductive services and right to sexual and reproductive health care services, etc. are also a part of this right (International Conference on Population and Development, 1994). The World Health Organization endorses the same definition as well. Thus, reproductive right is not a single unified right but is a bundle of rights which enable an individual to beget a child. The various human rights instruments have declared different elements of reproductive rights as human rights at international and regional levels. Most importantly, Article 23 (1) (b) of the International Convention on the Protection and Promotion of the Rights and Dignity of Persons with Disabilities, 2006, expressly confers the right to reproductive health and education. At the regional level, Article 14 of the Protocol to the African Charter on Human and Peoples Rights on the Rights of Women in Africa, 2003, declares that women's reproductive rights are also human rights.

Analysing the consolidation of reproductive human rights in European countries, we can conclude that, at the moment, it is insufficient and contains many gaps that, in some cases, leads to violations of human and civil rights. Overcoming these gaps are a complex process, and the case law of the European Court of Human Rights, which sets the standards to be met by the laws of the Member States, plays an important role (Mikhalkiv, 2020).

At the scientific level, there is no consensus on the specified term. A.O. Dutko and R.M. Swampy propose to understand reproductive rights as the guaranteed, state-sponsored opportunities for individuals to protect their reproductive health, free acceptance and the implementation of the decision to conceive a child or to refuse to have children by married or unmarried, methods of conception and birth of children, including with the help of assisted reproductive technologies, the number of children, time and place of birth, intervals between their births necessary to maintain the health of mother and child, as well as medical, social, informational and advisory assistance in this area (Dutko, 2016).

The evolution of the concept of reproductive rights as human rights can be traced back to the 1968 International Human Rights Conference held at Teheran. This document states that every parent has a fundamental human right to 
decide freely and responsibly about the number of children and the spacing in between such children. Subsequently, the Bucharest World Conference on Population, 1974, also declared in the similar manner and states that parents have a fundamental human right to decide about their children. Further, the international conferences, such as Women's Conference held in 1975; the Conference on Human Rights held in Vienna held in 1993; International Conference on Population and Development held in 1994; and the 1995 Beijing World Conference of Women etc., articulate reproductive rights as human rights. Among all these, the ICPD has been considered as the most important milestone in the history of development of reproductive rights.

The ICPD has identified three core elements of reproductive rights: the ability to control the timing of pregnancy, number, gap in between children's; access to information about reproductive services and a right against unwarranted interferences with such rights. In 1995, the Fourth World Conference on Women held in Beijing adopted a Declaration and Plan of Action thereby supporting the idea of reproductive rights. Though the Declaration and Plan of Action are non-binding in nature, they have highlighted that the human rights of women include the right to control and freely decide the matters relating to reproduction. The UN Millennium Development Goals, which were adopted in 2000, also emphasised the scope of right to procreation and urged the governments to focus on the issue of reproduction as it is one of the components of development. These commitments were further highlighted by different nations at the World Summit held in 2005; they agreed to take various measures for achieving the task of access to reproductive health care services by 2015 (Pillai, 2015). Among the various international instruments, the 2006 Convention on the Rights of Persons with Disabilities was the first binding international human right instrument which consolidated the right to reproduction as a human right. According to Article 23 of the Convention, it is the duty of every member-states to take adequate measures to eliminate barriers and discriminations against persons with disabilities in matters of parenthood. This also ascertains that such persons can decide the number and spacing of their children and are able to claim such rights equal to others. In process of time, in 2016, the General Comment № 22 related to Article 12 of the International Covenant on Social, Economic and Cultural Rights 1966, also has given emphasis to the right to sexual and reproductive health. The General Com- ment provides a detailed list about the obligations on the part of State Parties for ensuring these rights.

Protocol to the African Charter on Human and Peoples Rights on the Rights of Women in Africa is one of the important regional human rights instruments which protects the reproductive rights of women. This guarantees such important facets of reproductive rights as access to family planning and reproductive health care services. This Protocol reaffirms the duty of member's states to protect the reproductive choice and related rights of women. Both at Inter-American Human Rights system and European Human Rights system guarantee several reproductive rights, as follows: right to marriage; right to family; right to access to reproductive services; etc. Thus, it can be seen that reproductive rights are recognised as basic human rights both at international and national human rights frameworks.

3 . The scope of reproductive rights

The international and regional human rights frameworks declare that reproductive rights and its various facets are fundamental human rights. However, none of these documents have expressly declared the scope of this right. By relying on a literature review, it can be seen that there are two views on the scope of reproductive rights. The first view is a narrow stand under which scholars argue that reproductive rights include only a right to exercise reproductive choice. The foundation of this argument originates from the Convention on the Elimination of all forms of Discrimination against Women in 1979. The Article 16(1) (e) of the Convention states that every couple is entitled to have a right to procreation including access to sexual health and information and a right to decide the number and spacing of children. This view points out that the following rights are its core elements: the right to access to family planning information and education; the number and spacing of children; the right to access family planning methods and services; and the right to found a family; the right to decide, freely and responsibly.

The second view is much wider: it says that reproductive rights are an umbrella of human rights. This view finds its foundation in various national and international human rights instruments. Those scholars who support this view determines 12 human rights as the core elements of reproductive rights, namely: the right to marriage and free consent in marriage; right to education and information; right to privacy; right to health; right to security; right to employment; right against sexual harassment at workplace; right to maternity; right to reproductive choices; right against sexual violence; 
right to found family and right to enjoy benefit of scientific advancements (Gebhard, Trimiño, 2012). At international level, the scope of reproductive rights is well established through different international human rights documents. Further, several national jurisdictions also incorporated the reproductive rights in their municipal legal framework. However, the scope of this right in these countries will depend on the socio-political and religious views of those countries (Kostruba, 2020).

\section{Reproductive rights in India}

The Indian Constitution does not explicitly declare that reproductive rights are fundamental rights. Therefore, there is no legislation which declares an individual of reproductive rights. India is a party to most international human rights documents: UDHR, 1948; ICCPR, 1966; ICESCR, 1966; CDEDAW, 1979; and the Convention on Rights of Persons with Disabilities (2006). Consequently, all these documents expressly confer various facets of reproductive rights such as the right to privacy, the right to consent to marriage and equality in marriage, the right to access to family planning information and education; the right to found a family; the right to access to family planning methods and Services; the right to decide the number and spacing of one's children; and right to enjoy the benefits of scientific progress, etc. Hence, any individual in India can claim the abovementioned rights following the case Vishaka v. State of Rajasthan (AIR 1997 SC 3011), in which the Supreme Court held that, in the absence of a law regarding a particular matter in India, the international law can be referred to fill the legislative vacuum.

In addition, the Indian judiciary through various decisions has established reproductive rights under Article 21 of Indian Constitution. Most importantly, the judiciary has expanded the scope of right to personal liberty and right to privacy under Article 21 to cover reproductive rights. In the case of Suchita Srivastava v. Chandigarh Administration (AIR 2010 SC 235), the Supreme Court held that the right to reproduction of women has its base at right to life under Article 21. It includes right to reproduce as well as not to reproduce. Recently, in Devika Biswas v. Union of India ((2016) 10 SCC 726), Supreme Court has pointed out that that right to reduction includes the right to make free choice of sterilisation.

In B.K. Parthasarthy v. State of Andhra Pradesh (AIR 1973 SC 2701), the Supreme Court of Indian, by approving right to reproduction is a part of right to privacy, declared that "the right to make a decision about reproduction is essentially a very personal decision either on the part of the man or woman. Such a right necessarily includes the right not to reproduce". Further, in the recent case of Justice K.S. Puttaswamy (Retd) v. Union of India (2017(10) SCC 1), the Apex Court held that "Privacy is based on the preservation of personal intimacies, the sanctity of family life, marriage, procreation, the home and sexual orientation. Privacy also comprises a right to be left alone. Privacy safeguards individual autonomy and recognises the ability of the individual to control vital aspects of his or her life". Thus, an analysis of all these cases shows that the reproductive rights in India have attained the status of fundamental rights as a part of both right to personal liberty and right to privacy.

\section{Reproductive rights in Ukraine}

In Ukrainian civil science, several areas of understanding the nature and place of reproductive rights in the system of personal non-property rights of the individual have been formed: they have an independent separate character; have a close connection with the right to life; are considered an integral part of the right to health. Reproductive rights, of course, are a complex set of capabilities of the individual, aimed at ensuring the reproductive function of man to reproduce their own kind.

The system of reproductive rights should include: the right to reproductive choice; right to reproductive health; a woman's right to an abortion; the right to artificial insemination and embryotransfer intoawoman's body; the right to donate and preserve reproductive cells; right to application of the method of surrogacy; the right to sterilization; the right to use contraception; the right to prevention and treatment of infertility; the right to information on reproductive rights; the right to confidentiality of information on the exercise of reproductive rights; the right to protection of reproductive rights.

Reproductive rights also include the right to reproductive health services and the right to reproductive health, the right of minors to reproductive health, the right to paternity and maternity, the right to reproductive integrity and protection from cruelty (Mukhamiedova, 2012).

All the above rights are aimed at ensuring that every individual is free to own, use and dispose his or her reproductive health at his or her own will and discretion. As we can see, reproductive rights make up the whole system and their consolidation at the legislative level will contribute to their effective implementation and protection (Dluhopolska, 2016).

\section{Reproductive rights: legal dilemmas}

Reproductive rights and its various facets are fairly recognised both under international, regional and national human rights frameworks. However, the aspects of reproductive rights 
remain contentious, and the exercise of rights associated with reproductive rights poses a threat to Indian legal system. Here are some important issues.

\subsection{Right to abortion}

The termination of pregnancy or abortion is the expulsion or removal of a foetus from the uterus of a pregnant woman. In other words, abortion is the intended destruction of the life of an unborn child in the womb, otherwise than the principal purpose of producing a life birth or removal of a dead tissue (Ubajaka et al., 2014). Reproductive rights include right to legal and safe abortion. However, abortion in India is a punishable offence under Section 312 of Indian Penal Code, 1860. This Section describes abortion as intentional miscarriage and provides punishment both for pregnant women and the persons involved in such process. The punishment is simple or rigorous imprisonment for a term extending up to three years, or with fine, or both, and shall be punished with simple or rigorous imprisonment for a term extending up to seven years as well as shall also be liable to fine where the woman is quick with child. If the miscarriage is caused in good faith to save the life of the women, then this Section exempts them from liability. This means that, except in cases where the miscarriage is performed for saving life of the women, all other cases of abortion will be treated as an offence.

The Medical Termination of Pregnancy Act, 1971, has provided a restricted right to abortion. Under Section 3, it states that pregnancy may be terminated by a registered medical practitioner (a) where the length of the pregnancy does not exceed twelve weeks or (b) where the length of the pregnancy exceeds twelve weeks but does not exceed twenty weeks. However, termination can be done only if not less than two registered medical practitioners must have formed a bona fide opinion that (i) the continuance of the pregnancy would involve a risk to the life of the pregnant woman or grave physical or mental health injuries; (ii) there is a substantial risk that if the child were born, it would suffer from such physical or mental abnormalities as to be seriously handicapped. Explanation 1 of the Section states that, "where any pregnancy is alleged by the pregnant woman to have been caused by rape, the anguish caused by such pregnancy shall be presumed to constitute a grave injury to the mental health of the pregnant woman".

Explanation 2 states that "where any pregnancy occurs as a result of failure of any device or method used by any married woman or her husband for the purpose of limiting the number of children, the anguish caused by such unwanted pregnancy may be presumed to constitute a grave injury to the mental health of the pregnant woman". As per Section 5 of the Act, the length of the pregnancy and the opinion of not less than two registered medical practitioners mentioned under Section 3 shall not apply to the termination of a pregnancy by the registered medical practitioner in case where he/she is of the opinion in good faith, that the termination of such pregnancy is immediately necessary to save the life of the pregnant woman.

Thus, it can be seen that right to the termination of pregnancy can be exercised only in the following conditions:

1) the termination should be performed by a registered medical practitioner;

2) the length of the pregnancy must not exceed twenty weeks;

3) the continuance of the pregnancy would involve a risk to the life of the pregnant woman or of grave injury to her physical or mental health; or (ii) there is a substantial risk that if the child were born, it would suffer from such physical or mental abnormalities as to be seriously handicapped;

4) if the length of the pregnancy exceeds twenty weeks, only in cases of immediate necessity of to saving the life of the pregnant woman.

Thus, it can be seen that, although there is a right to legal and safe abortion which is established as a part of reproductive rights, only a qualified right to abortion is protected in India. Since the right to abortion is not an absolute right, reasonable restrictions can be imposed through a procedure established by law. In the case of Suchita Srivastava \& Anr. v. Chandigarh Administration (AIR 2010 SC 235), the Apex Court held that, right to reproduction includes a women's right to carry a pregnancy to its full term, to give birth and to subsequently raise children. However, in the case of pregnant women there is also a "compelling state interest' in protecting the life of the prospective child. Therefore, the termination of a pregnancy is only permitted when the conditions specified in the applicable statute have been fulfilled. Hence, the provisions of the MTP Act, 1971 can also be viewed as reasonable restrictions that have been placed on the exercise of reproductive choices". Thus, though there is a conflict between reproductive rights and abortion laws in India, considering the fact that right to abortion is not an absolute right and the overriding public interests, right to abortion may remain only as a qualified right (Kosgi et al., 2011).

\subsection{Single parent}

Reproductive rights are individual rights based on right to life and personal liberty. In this regard, a question arises whether a single individual, a male or female can claim 
reproductive rights, and if so, to what extent. In China, if any woman decides to exercise reproductive rights as single mother and gives birth to a child, she will be penalised and has to pay social up bringing cost to the government. In India, the laws are silent about the issue of procreation by single individual. Since reproductive rights are linked with right to marriage and found family, one inference can be made here is, only a person of marriageable age is entitled to claim reproductive rights. These types of restrictions are necessary considering the impact of pregnancy and child birth on the life of the adolescent. Various types of literature point out that, "adolescent pregnancy and child birth has severe impact on the has negative emotional, social and other aspects of the adolescent as well as the resulting child" (Mukhopadhyay, 2017). Thus, irrespective of the fact whether it is a single male or female, if the person completes his or her marriageable age, he or she should be given the core elements of reproductive rights.

\subsection{Aged individuals}

In most countries, the legislations are silent about the issue up to which age an individual can claim his right to procreation. However, considering the need to protect the interest of child, it is necessary to set a limit on the upper age up to which a person can claim his or her right to reproduction. It is to be noted that, in this context only the aspect of begetting a child is in dispute and not all other aspects of reproductive rights. This is because of reason that sometimes each and every aged person may not be able to protect the interests of child due to their physical and mental conditions. An analysis of various types of legal literature shows that it is impossible to fix a uniform upper age limit for begetting a child either sexually or through any other means. This is because there are cases in which a woman at the age of 74 years has given birth to a healthy baby. There are different similar incidents around the world (Oldest.org, 2020). However, in the interest of child, the use of reproductive rights for begetting a child should be limited. Such a limitation should follow the yardstick of physical condition of couple or individual and potential risks to the mother and child. If the couple or individual is capable enough to take care of child despite their age, or these persons have someone who can provide adequate care to the child, then they should be allowed to exercise the reproductive rights to beget a child (Brake, Millum, 2021).

\subsection{Persons with disabilities}

International human rights law gives robust recognition to both reproductive rights and rights of the disabled persons. In this con- text a pertinent question arises with respect to scope of reproductive rights of disabled persons. According to UN Convention on the Rights of Persons with Disabilities, 2006, "Persons with disabilities include those who have long-term physical, mental, intellectual or sensory impairments which in interaction with various barriers may hinder their full and effective participation in society on an equal basis with others". Thus, a disabled person means a person with one or more physical, mental, and sensory impairments which limit one or more of the basic life activities such as seeing, hearing, talking, walking, using hands, understanding, learning, communicating and inadequacies of a similar nature.

The issue of reproductive rights of persons with disabilities are addressed in the UN Convention on the Rights of Persons with Disabilities, 2006. Article 23 of the Convention specifically guarantees right to reproduction to all disabled persons without any discrimination and imposes an obligation to the members States to take adequate measures to ensure this right to everyone. Therefore, it can be seen that disabled persons are also entitled to have all reproductive rights without any discrimination, and it is the obligation of state parties to provide the same.

In India, the Rights of Persons with Disabilities Act, 2016, expressly guarantees the reproductive rights to all disabled persons. The Section 10 of the Act imposes an obligation to the Governments to take appropriate and adequate measures for ensuring reproductive rights of disabled persons. "No person with disability shall be subject to any medical procedure which leads to infertility without his or her free and informed consent". In the landmark case of Suchita Srivastava v. Chandigarh Administration (AIR 2010 SC 235), the apex Court has declared that even a mentally challenged woman can also claim reproductive right and can decide about her pregnancy. Consequently, there cannot be any distinction or discrimination to a person with disability in exercising his/her right to reproduction. However, it is noted that, in the interest of child, some restrictions can be imposed on the ground of the impact of disability on the natural upbringing and care of the child. If the physical or mental disability is of such a nature which adversely affects the upbringing, care and safety of the child, the exercise of reproductive rights to the extent begetting a child should be limited. Provided if there is anybody who can assist the disabled persons for taking care of child, then such disabled persons may be allowed to exercise the reproductive rights to beget a child (Lemberg, 2020). 


\subsection{Access to artificial human reproduc- tive technologies}

Every individual has a natural instinct to have a child and found a family. Begetting a child is a natural outcome of sexual union of heterosexuals. This process is socially accepted through the institution of marriage. Thus, human procreation is a common procuress which happens through the act of sexual intercourse between men and women. Therefore, there is no need of any intervention by another person or a technology. It only requires minimum medical assistance (Pillai, 2018). However, there are a large number of couples who are unable to have a child through biological process of procreation. This situation is medically termed as infertility. Infertility is a situation in which a couple is unable to conceive naturally even after one year of unprotected sexual intercourse or unable to carry the pregnancy to a full term (Anwar, Anwar, 2016). Infertility poses a severe crisis to the life of couples as they face several psychological issues which affect their personality, as a family member and as a member in the society.

In Indian society, the incapacity to procreate a child is considered as a stigma and is even regarded as a curse from God. Hence, the infertile couples look for various measures to overcome this problem. Traditionally, the option available to infertile couples is to go for adoption. The advancements in technology and medical science have paved the way for developing certain medical technologies through which an infertile couple can have a child of their own. These medical technologies which enable couples to have a child, who are otherwise unable to have children are collectively termed as Artificial Reproductive technologies (ARTs). There are many ARTs among which Artificial Insemination, Invitro Fertilisation and Surrogacy are the most popular and widely practiced methods (Vasilieva et al., 2019).

All individuals including infertile couples have the fundamental human right to reproduction. As a result, a pertinent question arises: whether such right to reproduction includes procreation of child with the help of artificial human reproductive technologies or, in other words, whether reproductive rights include access to ARTs (Pillai, 2014). The use of ARTs for begetting children is very rampant in different countries. However, none of the international human rights documents have referred the issue of right to access to ARTs. Though access to ART has not been yet expressly declared as a part of reproductive rights, the access to ART is inherent in reproductive rights. This is because an infertile couple cannot enjoy their reproductive rights without the help of ART. This view is supported by various scholars like Jackson and Harris, who opined that, "interference with access to reproductive technologies is a violation of procreative autonomy, and that the real or perceived dangers of possible harm are insufficient to justify constraints" (Harris, 2000).

Moreover, the right to access to ART can be considered as a facet of other well established human rights such as right to marriage; right to found a family; right to privacy; right to procreation, right to control the number and spacing of their children and right to enjoy benefits of scientific and technological advancements (Pillai, 2015). It is to be noted here, the right to access to ART is not an absolute right like many other rights and hence reasonable restrictions can be imposed by state. In India, there is no specific legislation dealing with ART, however, there are National Guidelines for Accreditation, Supervision \& Regulation of ART Clinics in India (popularly known as ICMR Guidelines, 2005) which recognise the right to access to ART. However, it is essential to note that this is a non-binding instrument. Further in several cases relating to surrogacy such as Baby M. Yamada v. Union of India (AIR 2009 SC 84) and in the case of Jan Balaz v. Anand Municipality and Ors (AIR. 2010 Guj. 21), the Indian judiciary has approved that there is a fundamental right to access ART (i. e. to Surrogacy) (Pillai, 2018). Though the proposed Surrogacy Bill, 2019, has provided some eligibility conditions, the Bill has undergone severe revision by Rajyasabha Selection Committee and, as a result, the Bill has lost its shape and with all probability it will remain as a Bill only and not become a law.

\subsection{Same sex couples}

The same sex relationships are higher in the past few decades and as a result several countries have legally recognised such relationships. This has resulted in the practice of same sex marriage (Re Patrick, 2002). In such family one figure i. e. wife or husband is always absent and hence they won't be able to have a child through natural sexual union (Nigam et al., 2011). It is to be noted that, such couples also have a natural desire to have a child of their own, similar to the desire of hetero sexual couples (Pillai, 2015). It is to be noted that same sex couples cannot exercise their reproductive rights like other individuals and hence they have to use any of ARTs to enjoy the benefit of reproductive rights. Though access to ART can be considered as a part of reproductive rights in India, the exercise of such rights can be restricted on compelling public interest.

The use of ART by gay and lesbian couples where always a matter of debate. It is argued that, same sex couples are also human beings 
so they are entitled to have all the rights like any other hetro sexual couple. This includes procreation with the help of ART also. It is also argued that parenting is not always depends upon sex and even a same sex couple can also raise a child properly. However, these claims by same sex couples where criticised on the ground of absence of father figure or mother figure for the child. There may be cases where father or mother or both may die after the birth of child, however, in cases of same sex couples such a figure is completely absent. This can affect the character and mental wellbeing of the child. Moreover, the stigma of taking birth to a same sex couple will haunt the child life long (Dent, 2011). Whatever be the arguments, it is to be noted that various studies have shown that, the same sex parents can also be a good parents like hetero sexual parents (Fraser et al., 1995). Thus, it is submitted that same sex couples should be allowed to use the reproductive rights (or in other words use ART). However, the State can impose reasonable restrictions for the protection and promotion of welfare of children and societal interest.

\subsection{Trans-gender persons}

Another related issue which arises in this context is the claim of reproductive rights by trans-genders. Trans-genders are a group of people are not able to identify as a men or women and have traits and physical features of both men and women (Nixon, 2013). According to Indian law, "A transgender person means a person whose gender does not match with the gender assigned to that person at birth and includes trans-man or trans-woman (whether or not such person has undergone Sex Reassignment Surgery or hormone therapy or laser therapy or such other therapy), person with intersex variations, gender queer and person having such socio-cultural identities as kinner, hijra, aravani and jogta" (Section 2(k) of Transgender Persons (Protection of Rights) Act, 2019).

In the case of National Legal Services Authority v. Union of India (AIR 2014 SC 1863), the Supreme Court declared that transgender persons are entitled to claim fundamental rights like any other person without any distinction. Thus, as a natural corollary, the reproductive rights which are part of right to personal liberty and right to privacy under Article 21 also should be available to transgender persons. In 2019, the Parliament of India has enacted, Transgender Persons (Protection of Rights) Act, 2019 with the objective to provide for protection of rights of transgender persons, their welfare, and other related matters. However, this Act is silent about the reproductive rights of trans-genders. It can be argued that, trans-gender persons should also be allowed to enjoy the reproductive rights, but the State can create reasonable restrictions on account of compelling public interest and for the interest of child.

\subsection{Prisoners}

A prisoner is a person who is undergoing a sentence of imprisonment or undergoing imprisonment awaiting trial. It is a natural consequence that several aspects of fundamental and other rights of persons will be deprived while he/she is serving as a prisoner in a jail. In this context the question, arises whether right to reproduction survives incarceration and where such a right can be identified under Indian Constitution. In the case of Sumeet Bajwa v. State of Punjab \& Ors ((2016), CWP № 2239 of 2015), the Punjab and Haryana High Court held that, right to procreation is available even when a person undergoing imprisonment. Because such right is a part of right to life under Article 21 of the Constitution when it is read together UDHR. Therefore, in India a female prisoner is also entitled to claim right to procreation. However, for the purpose of protecting public interest and interests of the child, reasonable restrictions can be imposed upon the exercise of these rights by prisoners.

\subsection{Posthumous reproduction}

The development in medical science has paved the way for preservation of reproductive materials and use such materials after the death of the person. One such use of medical technology is procreation using reproductive materials which were stored prior to the death of any one or both parents. This type of procreation is generally called as posthumous reproduction. "Posthumous reproduction is commonly used to refer to the intentional application of advanced medical technologies to achieve conception, pregnancy and childbirth in a situation where one or both parents are declared dead" (Hashiloni-Dolev, Schicktanz, 2017). Therefore, posthumous reproduction occurs when a child is born after one or both genetic parents have died (Robertson, 1994).

Generally, there are various circumstances in which people seek to procreate posthumously a child using the gametes of a deceased person. For instance, a surviving spouse or intimate friend seeks to use the gametes which have been specifically cryo preserved for use prior to the death of the loved one. Examples include situations in which a soldier or other person engaged in high-risk activity cryopreserve his or her gametes. Another example is when a dying or seriously ill person cryopreserves gametes for use by specifically named potential survivors. In other instances, an untimely death may create a situation in which gametes become available even though the deceased person did not 
anticipate death and therefore did not specifically consent before death (Kindregan, 2009).

In the context of reproductive rights, one may argue that right to use posthumous reproduction is also part of reproductive rights. It is to be noted that in case of a posthumous reproduction, there may be legal disputes regarding the legitimacy of the child; parentage; right to inheritance; right to custody; and right to maintenance. These issues are very complicated and challenging due to the fact one or both the parents have died before the birth of the child. Thus, any expansion of reproductive rights to the extent that to cover right to posthumous reproduction need to take into account the rights and welfare of the innocent child.

\section{Conclusions}

Nature has bestowed the beautiful capacity to procreate a life within every individual and every woman cherishes the experience of motherhood. As a result, every couple has the innate desire to have a child, and this is recognized through reproductive rights. However, none of the general international human rights instruments expressly declares reproductive rights as human rights. The only international instrument which makes an express declaration about reproductive rights is the Convention on Persons with Disabilities, 2006. This doesn't mean that international human rights law is silent about reproductive rights. These documents guarantee several facets of reproductive rights in some ways. Therefore, it can be seen that, at the international level, the human rights law establishes a good framework for reproductive rights. This framework emphasises that reproductive right is not a single human right but a bundle of other related human rights. The most important rights which come under the umbrella of reproductive right are: right to privacy; right to equality; right against discrimination; right to marriage; right to found family; right against sexual violence; right to freely decide; right against coercion; right to decide number and spacing; right to marriage; right against fore full marriage; right to maternity; right to take advantages of scientific advancements, etc.

India and Ukraine are parties to all major international human rights treaties. Hence, the various facets of reproductive rights are also applicable in our country. Consequently, national judiciary has interpreted right to personal liberty and right to privacy in such way as to cover all the facets of reproductive rights. Thus, it can be observed that in our country has a well-established framework for reproductive rights as well. However, the various legal dilemmas identified in the above chapter need to be addressed legally to strike a balance between the reproductive rights of individuals with the interest and well-being of children and with the societal interest.

\section{References:}

Anwar, S., Anwar, A. (2016). Infertility: A Review on Causes, Treatment and Management. Women's Health $\mathcal{E}$ Gynecology, no. 2(6), pp. 1-5 (in English).

Brake, E., Millum, J. (2021). Parenthood and Procreation. Retrieved from: https://plato.stanford.edu/ entries/parenthood/ (in English)

Dent, G.W. (2011). No Difference?: An Analysis of Same-Sex Parenting. Retrieved from: https://scholarlycommons.law.case.edu/faculty_publications/570 (in English).

Dluhopolska, T. (2016). Pravova pryroda reproduktyvnykh prav fizychnykh osib [Legal nature of reproductive rights of individuals]. Aktualni problemy pravoznavstva - Actual problems of jurisprudence, no. 2, pp. 103-107. Retrieved from: http://nbuv.gov.ua/UJRN/aprpr_2016_2_21 (in Ukrainian).

Dutko, A.O. (2016). Reproduktyvni prava fizychnoi osoby: sutnist, poniattia ta klasyfikatsiia [Reproductive rights of an individual: essence, concept and classification]. Naukovyi visnyk Lvivskoho derzhavnoho universytetu vnutrishnikh sprav. Seriia "Yurydychna" - Scientific Bulletin of Lviv State University of Internal Affairs. Series "Legal Sciences”, no. 3, pp. 82-90 (in Ukrainian).

Erikson, M.K. (2000). Reproductive Freedom. Hague: Martinus Nijhoff (in English).

Fraser, I.H., Fish, T.A., MacKenzie, T.M. (1995). Reactions to Child Custody Decisions involving Homosexual and Heterosexual Parents. Canadian Journal of Behavioral Science, no. 27(1), pp. 52-63 (in English).

Gebhard, J., Trimi o, D. (2012). Reproductive Rights, International Regulation. Max Planck Encyclopaedia of Public International Law. Retrieved from: https://www.corteidh.or.cr/tablas/r16912.pdf (in English).

Harris, J. (2000). Rights and reproductive choice. HarrisJ., Holm S. (eds.) The Future of Human Reproduction. Oxford: Clarendon Press, pp. 34-36 (in English).

Hashiloni-Dolev, Y., Schicktanz, S. (2017). A Cross-Cultural Analysis of Posthumous Reproduction: The Significance of the Gender and Margins-of-Life Perspectives. Reproductive Biomedicine E Society Online, no. 4, pp. 21-32 (in English).

High Court of Gujarat at Ahmedabad (2010). Jan Balaz Vs. Anand Municipality and 6 Ors. (AIR 2010 Guj. 21) (in English). 
International Conference on Population and Development (1994). Program of Action, UN Doc. A/CONF.171/13 1994, chap. 7.A (in English).

Kindregan, C.P. (2009). Dead Dads: Thawing an Heir from the Freezer. William Mitchell Law Review, vol. 35, no. 2, pp. 433-448. Retrieved from: https://ssrn.com/abstract=1443447 (in English).

Kosgi, S., Hegde, V.N., Rao, S., Undaru, S.B., Pai, N.B. (2011). Women's Reproductive Rights in India: Prospective Future. Online Journal of Health and Allied Sciences, no. 10(1), pp. 1-5 (in English).

Kostruba, A. (2020). Right deprivation in the legal regulation mechanism of civil property relations: comparative analysis of international legislation. Asia Life Sciences, no. 22(2), pp. 143-156. Retrieved from: https://zenodo.org/record/4034445\#.YVxFZkhR2Uk (in English).

Lemberg, D. (2020). Procreative Liberty - Are There Limits? Retrieved from: https://www.amc.edu/ BioethicsBlog/post.cfm/procreative-liberty-are-there-limits (in English).

Mikhalkiv, I.M. (2020). Reproduktyvni prava liudyny v aspekti statti 8 YeKPL: ohliad praktyky YeSPL [Human reproductive rights in the aspect of article 8 of the ECHR: review of the ECHR practice]. Yurydychnyi naukovyi elektronnyi zhurnal - Juridical scientific and electronic journal, no. 3, pp. 466-469. Retrieved from: https://doi.org/10.32782/2524-0374/2020-3/112 (in Ukrainian).

Mukhamiedova, E.E. (2012). Reproduktyvni prava fizychnoi osoby v systemi osobystykh nemainovykh prav [Reproductive rights of an individual in the system of personal non-property rights]. Uchenye zapiski Tavricheskogo natsional'nogo universiteta imeni V.I. Vernadskogo. Seriya "Yuridicheskie nauki" - Scientific notes of Taurida National V.I. Vernadsky University. Series "Juridical Sciences", vol. 25(64), no. 2, pp. 136-141 (in Ukrainian).

Mukhopadhyay, T. (2017). Women's reproductive rights are human rights. Retrieved from: http://hdr.undp.org/en/content/women\%E2\%80\%99s-reproductive-rights-are-human-rights (in English).

Nigam, M., Nigam, R., Chaturvedi, R., Jain, A. (2011). Ethical and Legal aspects of Artificial Reproductive Techniques including Surrogacy. Anil Aggrawal's Internet Journal of Forensic Medicine and Toxicology, no. 12(1) (in English).

Nixon, L. (2013). The Right to (Trans) Parent: A Reproductive Justice Approach to Reproductive Rights, Fertility, and Family-Building Issues Facing Transgender People. William E Mary Journal of Women and the Law, no. 20(1), pp. 73-103 (in English).

Oldest.org (2020). 8 Oldest Pregnant Women Ever in the World. Retrieved from: https://www.oldest.org/ people/pregnant-women/ (in English).

Pillai, A.V. (2014). Assisted Human Reproductive Technologies: Legal Issues and Challenges in India. Delhi: Scholars' Press (in English).

Pillai, A.V. (2018). Right to Access to Human Reproductive Technologies under Indian Legal Framework: A Bird's View. GLS Law Journals, no. 1(1), pp. 1-8 (in English).

Pillai, A.V. (2015). Surrogate Motherhood and the Law: International \& National Perspectives. Delhi: Regal Publications (in English).

Punjab-Haryana High Court (2016). Sumeet Bajwa vs State of Punjab \& Ors. CWP № 2239 of 2015 (in English).

Re Patrick (2002). 28 Family Law Reports, 579, 650 (US) (in English).

Robertson, J.A. (1994). Posthumous Reproduction. Indiana Law Journal, vol. 69, iss. 4. Retrieved from: https://www.repository.law.indiana.edu/ilj/vol69/iss4/8 (in English).

Supreme Court of India (1973). B. K. Parthasarthy v. State of Andhra Pradesh. AIR 1973 SC 2701, 1974 SCR (1) 697, 1974 SCC (3) 459 (in English).

Supreme Court of India (1997). Vishaka and others v. State of Rajasthan and others. 6 SCC 241, AIR 1997 SC 3011, (1998) BHRC 261, (1997) 3 LRC 361, (1997) 2 CHRLD 202 (in English).

Supreme Court of India (2008). Baby Manji Yamada vs. Union of India and Another. 13 SCC 518 and in the Matter of Baby M, 217 N.J. Super 313, (1987). AIR. 2010 Guj. 21 (in English).

Supreme Court of India (2010). Suchita Srivastava and Anr. V. Chandigarh Administration. AIR 2010 SC 235 in context with Medical Termination of Pregnancy Act, 1971 (in English).

Supreme Court of India (2014). National Legal Services Authority v. Union of India. AIR 2014 SC 1863 (in English).

Supreme Court of India (2016). Devika Biswas v. Union of India. AIR 2016 SC 4405, 2016 (4) RCR 461 (Civil), 2016 (8) SCALE 707, 2016 (10) SCC 726 (in English).

Supreme Court of India (2017). Justice K. S. Puttaswamy (Retd) v. Union of India. (10) SCC 1 (in English).

Ubajaka, C.F., Adogu, P., Ilika, C., Ilika, A.L. (2014). Perception of Abortion and Abortion Laws by Lawyers in Anambra State Nigeria. International Journal of Clinical Medicine, no. 5(12), pp. 695-703 (in English).

Vasilieva, V.A., Stefanyshyn, N.B., Skhab-Buchynska, T.Ya. (2019). Surrogate Motherhood: Analysis of the Basis of the Legislation of Ukraine and Foreign Countries. Journal of Advanced Research in Law and Economics, no. 9(6), pp. 2176-2189. DOI: 10.14505//jarle.v9.6(36).33 (in English). 
Аніш В. Піллаї,

доктор філософії, дочент, ШКкола юоридичних досліджень Кочинського університету науки і технологій, Каламассері, Кочі Керала, Індія, індекс 682022, advavpillai@gmail.com, dr.avpillai@cusat.ac.in

ORCID: orcid.org/0000-0002-1889-8221

Анатолій Коструба,

доктор юридичних наук, професор кафедри иивільного права, Прикарпатський начіональний університет імені Василя Стефаника, вулиия Шевченка, 57, Івано-Франківськ, Україна, індекс 76000, anatolii.kostruba@pпи.edu.ua

ORCID: orcid.org/0000-0001-9542-0929

\section{РЕПРОДУКТИВНІ ПРАВА ЖІНОК: МІЖНАРОДНІ ПРАВОВІ МЕЖІ}

Анотація. Статтю присвячено проблемі природи та ролі репродуктивних прав особи в системі особистих немайнових прав. Метою публікації $€$ вивчення стану правового регулювання репродуктивних прав жінок в Індії та Україні, аналіз особливостей деяких репродуктивних прав, які здійснюються за допомогою допоміжних репродуктивних технологій, з акцентом на сурогатному материнстві, а також розгляд прецедентної практики із цього питання. Методи дослідження. Статтю виконано із застосуванням загальних досліджень та спеціальних методів наукового пізнання.

Результати. Репродуктивні права загалом означають право особи контролювати процес відтворення. Воно включає право вирішувати, чи мати дитину, яку кількість дітей народжувати та з якими часовими проміжками, а також доступ до репродуктивних послуг тощо. 3 огляду на важливість і значення відтворення людини репродуктивні права оголошуються основними правами людини. Однак на міжнародному й національних рівнях немає єдиного документа, який пояснював би обсяг репродуктивних прав. За відсутності такого акта репродуктивні права викликають декілька питань. Наприклад, питання обсягу зазначеного права для літньої людини, інваліда, трансгендера, в’язня тощо є актуальним, проте залишається без конкретної відповіді. 3 огляду на те, що розширення прав і можливостей жінок включає репродуктивні можливості жінок, необхідно надати чітку й розумну відповідь на зазначені питання для досягнення мети репродуктивних можливостей. Для цього необхідний детальний огляд правових основ на міжнародному та національному рівнях.

Висновки. Обгрунтовано наукові позиції щодо репродуктивних прав. Підкреслено, що репродуктивні права - це права останнього, четвертого, покоління прав людини, вони походять від особистих прав. Констатовано, що репродуктивні права людини є як природними, так і тими, що реалізуються з використанням допоміжних технологій. У статті досліджуються основні види репродуктивних прав, зокрема право на штучне запліднення, право на сурогатне материнство, право на стерилізацію, право на профілактику та лікування безпліддя, право на аборти, право на донорство органів і репродуктивні клітини, право на використання контрацепції, право на репродуктивний вибір, право на репродуктивне здоров'я, право на інформацію про репродуктивні права, право на конфіденційність для реалізації репродуктивних прав тощо. Обгрунтовано необхідність прийняття спеціального законодавчого акта у сфері репродуктивних прав і репродуктивного здоров'я.

Ключові слова: репродуктивні права, особисті права, особистість, медичне право, права людини, право на приватне життя, аборт, стерилізація, допоміжні репродуктивні технології, сурогатне материнство, штучне запліднення, медичний туризм.

The article was submitted 01.08.2021

The article was revised 20.082021

The article was accepted 10.09.2021 